\title{
ROLE OF SYSTEMIC OMALIZUMAB IN MANAGEMENT OF ALLERGIC FUNGAL RHINOSINUSITIS
}

\author{
Badr Eldin Mostafa, Mohammed A. Hassan, Tarek Hamdi, Anas Askoura and \\ Michael Mounir
}

Department of

Otorhinolaryngology, Ain-

Shams University Faculty of

Medicine, Cairo, Egypt

Corresponding author:

Badr Eldin Mostafa

Mobile: 12227460989

E mail:

bemostafa@gmail.com

Received: 22/4/2019

Accepted: 21/5/2019

\begin{abstract}
:
Background: Allergic fungal rhinosinusitis (AFRS) is due to the continuous exposure of fungal antigens to an atopic individual. It is caused by type I, IgE mediated (and possibly type III) hypersensitivity reaction to an extramucosal fungal antigen. Medical treatment following the surgery is the standard protocol of management. Steroids (systemic/topical) have been considered as the standard medical treatment for control of the disease despite high recurrence rate and their serious side effects. Instead, omalizumab, a humanized monoclonal anti-IgE antibody, can be tried as a new treatment modality with less side effects to control symptoms and decrease the recurrence rate in AFRS patients. It acts by aborting the immunological reaction to sinonasal fungi through preventing the release of inflammatory mediators that cause allergic signs and symptoms.
\end{abstract}

Aim: To evaluate the role of omalizumab for postoperative management of AFRS patients in comparison to topical steroids as regarding symptom free interval and side effects.

Patients and methods: A total of 20 patients with AFRS were included in the study. Patients were divided randomly into two equal groups: group A used local steroid and group B used single dose of subcutaneous omalizumab. Clinical parameters were compared at 4,8,12 and 24 weeks.

Results: Although there was no statistical significant difference between both groups as regards endoscopic nasal examination posttreatment, patients of group $B$ were statistically better as regards clinical and subjective parameters.

Conclusion: We suggest that omalizumab has more superior effect than local steroids in controlling nasal symptoms in AFRS patients despite the same endoscopic scores post-treatment. More well-designed large prospective randomized controlled trials to determine the effects and optimal dosage and duration of omalizumab therapy in patients with AFRS will be necessary.

Keywords: Nasal polyps, hypersensitivity, sinusitis, Aspergillosis, steroids, omalizumab, Anti-Immunoglobulin E.

\section{INTRODUCTION:}

Allergic fungal rhinosinusits (AFRS) accounts for 5 to $10 \%$ of all cases of chronic rhinosinusitis (CRS) requiring surgery worldwide $^{[1]}$. It is a disease found mainly in areas of high humidity ${ }^{[2,3]}$. Due to its chronic nature, it represents high economic burden throughout the world ${ }^{[4]}$. The 
pathophysiological basis of AFRS is associated with type I IgE-mediated allergic response to inhaled mold spores that are present in the environment in a predisposed person (and to a lesser extent type III response $)^{[5]}$.

Treatment of AFRS usually involves surgery in the form of endoscopic sinus surgery (ESS) in combination with medical therapies to control its chronic nature. However, the optimal medical regimen is still vague ${ }^{[6,7]}$. Medical therapy usually includes systemic corticosteroids, local steroids, antifungal agents and immunetherapy ${ }^{[8]}$. Oral corticosteroids are used usually to control symptoms, endoscopic and radiological nasal scores ${ }^{[9]}$. However, longterm oral corticosteroid use is problematic with serious side effects. This requires the presence of alternative options for disease control with minimal side effects such as metered dose topical corticosteroids ${ }^{[10,11]}$. However, the accessibility of the metered dose topical steroids to sinus mucosa can be difficult owing to the occlusion of surgically opened sinus ostia due to significant inflammation in $\mathrm{AFRS}^{[12,13]}$.

There is a number of patients who are refractory to these treatments modalities (ranging from $10 \%$ to about $100 \%$ depending on the length of follow-up period), beside their serious side effects. Thus, the search for a salvage therapy continues ${ }^{[14]}$. Reduction of IgE level may have a potential benefit in patients refractory to other treatment modalities owing to blunting the immune response to nasal fungal infection $^{[15,16,17]}$. Also, immunotherapy results in decrease need for oral steroid therapy in AFRS patients ${ }^{[18]}$.

Omalizumab is a humanized monoclonal anti-IgE antibody that has been shown to be an effective adjuvant therapy in severe atopic asthma and allergic rhinitis ${ }^{[19]}$. It decreases free $\operatorname{IgE}$ levels by binding to free circulating IgE. This process inhibits the binding and cross linking of $\operatorname{IgE}$ to the high- affinity $\operatorname{IgE}$ receptors on surface of mast cells and basophils., thereby preventing the release of inflammatory mediators that cause allergic signs and symptoms ${ }^{[20]}$.

\section{THE AIM OF THE WORK:}

The aim of the study is to evaluate the role of omalizumab for postoperative management of allergic fungal rhino sinusitis in comparison to topical steroids as regarding symptom free interval and side effects.

\section{PATIENTS AND METHODS:}

The present study is a two-arm prospective (Case-Control), randomized, single blind clinical trial among patients with allergic fungal rhinosinusitis presenting to Otorhinolaryngology Department, Ain Shams University Hospitals. It was conducted during the period from October 2017 to January 2019. This study has been approved by the ethical committee.

Inclusion criteria were as the following:

All cases with AFRS presenting during the study period with or without previous surgical intervention after failure of medical treatment in the form of systemic steroids (oral prednisolone $30 \mathrm{mg}$ gradual tapering dose) for one month and local steroids for at least 2 months duration of therapy. The treatment was discontinued 3 weeks before conduction of the study.

Criteria for diagnosis of AFRS in this study are based on Bent and Kuhn's ${ }^{[21]}$ diagnostic criteria of AFRS which are: type I hypersensitivity, nasal polyps, characteristic CT scan findings, positive fungal stain or culture and allergic mucin with no tissue invasion.

Exclusion criteria:

a) Cases with allergic non fungal rhinosinusitis. Cases with other forms 
of fungal rhinosinusitis (eg: invasive forms).

b) History of one of the following: Severe idiopathic anaphylactic reaction; prior exposure to omalizumab or immunetherapy within the past 2 years; parasitic infection; history of perennial or vasomotor rhinitis; presence immunecompromised state; clinically significant ECG abnormality; pregnancy and lactation, and low platelet count.

The patients were randomly assigned to one of two groups:

1. Group A [Omalizumab group]: 10 patients to receive a single dose of omalizumab (Xolair ' Novartis) in the form of subcutaneous injection (150 $\mathrm{mg}$ single-dose vial with lyophilized, sterile powder for reconstitution). The dose regimen respects patient's body weight irrespective to patient's total IgElevel. The injection was given two weeks postoperatively.

2. Group B (controls): 10 patients to receive local steroids nasal sprays (Budesonide or Mometasone Furoate, 2 sprays $(100 \mathrm{mcg})$ in each nostril twice daily for six months). Treatment was also started 2 weeks postoperatively.

All patients were enrolled under the strict guidelines of the committees on clinical investigation and ethics guidelines and gave informed consent. All patients underwent the following:

1. History taking and examination includes endoscopic nasal examination.
a. Sino-Nasal Outcome Test (SNOT-20) scoring.
b. Total Nasal Symptom Score (TNSS).

2. Preoperative non contrast Computed Tomography "CT" of nose and paranasal sinus, $5 \mathrm{~mm}$ axial cuts and coronal reconstruction cuts). Scores of
CT findings (The Lund-Mackay CT scores) were used ${ }^{[22]}$.

3. Serum total $\mathrm{IgE}(\mathrm{IU} / \mathrm{mL})$ level assessments by ELISA (Human IgE ELISA Kits, Life Span Bio Sciences, Inc. USA).

4. Surgery: All selected patients underwent endoscopic sinus surgery (ESS). Intraoperatively, disease staging was performed by the Philpott-Javer endoscopic staging for AFRS ${ }^{[23]}$.

5. Histopathological examination of postoperative specimens: H\&E stain and PAS fungal stain to diagnose non invasive fungal infection.

6. Follow up :

Patients were followed at the end of four, eight, twelve and twenty four weeks post-treatment (six months). The following data were collected from the patients' charts:

- Change in sinonasal symptoms before and after therapy.

- Change in serum total IgE level.

- Change in endoscopic mucosal disease before and after therapy.

- Documented side effects from therapy within both groups.

\section{RESULTS AND DATA ANALYSIS:}

A total of 20 patients were enrolled in our study randomly divided into two equal groups. Description of the patients' data was as follow: Group A: there were 10 patients, 6 female and 4 males. The mean age was $24.6 \pm 8.57$ (16 - 41 years), and the majority of cases were newly diagnosed (80\%). Group B: consisted of 10 patients, 5 females and 5 males. The mean age was $24.3 \pm 7.24$ (14 36 years), and the majority of cases were newly diagnosed too $(70 \%)$. There was no significant difference between the two study groups as regards personal and medical data. 
Preoperative and intraoperative assessment parameters show also no statistical significant difference between cases of the two study groups (Table 1).

Comparison between the two study groups as regarding postoperative assessment parameters after 24 weeks of treatment revealed a highly significant difference $(p=0.001)$ between post-operative TNSS scores in group A (Mean $4.2 \pm 1.14$ ) and group B (Mean $7.9 \pm 1.1$ ). Also, there was a significant difference between postoperative SNOT-20 scores in group A $($ Mean $=12.9 \pm 7.05)$ and group B $($ Mean $=$ $30.7 \pm 7.33$ ) with $p$ value equals 0.02 .
There was no statistically significant difference between the two study groups as regarding postoperative total IgE level measured at 4 and 8 weeks. However, postoperative total $\operatorname{IgE}$ level measured at 12 weeks showed a significant difference $(\mathrm{p}=$ 0.02 ) between study group A (Mean $=295.8$ $\pm 213.78)$ and study group $B($ Mean $=627.5$ \pm 300.27 ). After 24 weeks, there was no statistically significant difference again between the two study groups. No significant difference was found between the two study groups as regarding changes in the post-operative endoscopic Phillpott-Javer staging scores $(\mathrm{p}=0.144)$ (table 2$)$.

Table (1): Comparison between the 2 study groups as regards pre-operative and intraoperative assessment parameters

\begin{tabular}{|c|c|c|c|c|c|c|c|c|c|c|c|c|}
\hline & \multicolumn{10}{|c|}{ Group } & \multirow{3}{*}{$P$} & \multirow{3}{*}{ Sig } \\
\hline & \multicolumn{5}{|c|}{ Group A } & \multicolumn{5}{|c|}{ Group B } & & \\
\hline & Mean & $\pm \mathrm{SD}$ & Median & \multicolumn{2}{|c|}{ IQR } & Mean & $\pm \mathrm{SD}$ & Median & \multicolumn{2}{|c|}{ IQR } & & \\
\hline Preoperative SNOT-20 & 67.1 & 6.9 & 67.0 & 62.0 & 73.0 & 63.1 & 7.5 & 62.5 & 55.0 & 70.0 & $0.23^{* *}$ & $\mathrm{NS}$ \\
\hline Preoperative TNSS & 11.2 & 1.0 & 11.0 & 10.0 & 12.0 & 10.6 & 1.3 & 11 & 10.0 & 12.0 & $0.27^{* *}$ & NS \\
\hline $\begin{array}{l}\text { Preoperative Lund- } \\
\text { Mackay CT scores }\end{array}$ & 19.6 & 5.0 & 21.5 & 18.0 & 23.0 & 18.2 & 3.9 & 18.5 & 15.0 & 21.0 & $0.49^{* *}$ & NS \\
\hline Preoperative total IgE & 926.1 & 678.5 & 910.5 & 358.0 & 1232.0 & 763.4 & 381.0 & 840 & 463.0 & 988.0 & $0.7 *$ & NS \\
\hline $\begin{array}{l}\text { Intraoperative Phillpott- } \\
\text { Javer staging }\end{array}$ & 65.3 & 16.0 & 72.5 & 53.0 & 75.0 & 62.7 & 13.7 & 65 & 62.0 & 72.0 & $0.28^{*}$ & NS \\
\hline
\end{tabular}

-IQR: Interquartile range, ${ }^{*}$ Mann-Whitney Test, ${ }^{* *}$ Student $t$ test

Table (2): Comparison between the 2 study groups as regarding postoperative assessment parameters after treatment

\begin{tabular}{|l|c|c|c|c|r|c|}
\hline \multirow{2}{*}{} & \multicolumn{3}{|c|}{ Group } & \multirow{2}{*}{ P } & \multirow{2}{*}{ Sig } \\
\cline { 2 - 6 } & \multicolumn{2}{|c|}{ Group A } & \multicolumn{2}{|c|}{ Group B } & \\
\cline { 2 - 7 } & Mean & \pm SD & Mean & \pm SD & & \\
\hline Postoperative SNOT-20 scores & 22.9 & 7.05 & 30.7 & 7.33 & $0.02^{* *}$ & S \\
\hline Postoperative TNSS scores & 4.2 & 1.14 & 7.9 & 1.10 & $0.001^{* *}$ & HS \\
\hline Postoperative total IgE(4 weeks) & 573.1 & 338.28 & 676.0 & 343.32 & $0.5^{*}$ & NS \\
\hline Postoperative total IgE(8 weeks) & 392.7 & 245.74 & 660.0 & 297.65 & $0.057^{*}$ & NS \\
\hline Postoperative total IgE(12 weeks) & 295.8 & 213.78 & 627.5 & 300.27 & $0.02^{*}$ & $\mathrm{~S}$ \\
\hline Postoperative total IgE(24 weeks) & 431.7 & 291.59 & 644.1 & 289.53 & $0.12^{*}$ & $\mathrm{NS}$ \\
\hline Postoperative Phillpott-Javer stage & 19.4 & 9.65 & 24.9 & 9.71 & $0.1 *$ & $\mathrm{NS}$ \\
\hline
\end{tabular}

*Mann-Whitney Test, **Student $t$ test

As regarding side effects within group A: only one case complained of nasopharyngitis ( $10 \%$ complication rate). Within group B: one patient had crustations formation. Another patient complaint of epistaxis and a third patient had nasal burning sensation (complication rate 30\%). There was no statistical significant differe- 
nce in complication rate between the two study groups $(p=0.582)$.

\section{DISCUSSION:}

Treatment of AFRS is controversial. Different treatment protocols have been used to overcome recurrences including both medical and surgical care ${ }^{[24,25]}$. AFRS may represent an immunologic, rather than an infectious disease process. That is why reduction of IgE level by immunotherapy may have a potential benefit in patients refractory to other treatment modalities ${ }^{[26,27]}$.

In our study, all patients were treated by endoscopic sinus surgery under general anaesthesia. Postoperatively, these patients were divided randomly into two groups of 10 patients each with different treatment plan. Postoperative follow up was done at $4,8,12$ and 24 weeks using the same preoperative parameters and scores (subjective questionnaires, radiological, endoscopic and laboratory scores).

Upon comparison between both groups postoperatively, group A patients were better than group B patients as regards the subjective parameters (TNSS scores and SNOT-20 scores) and symptoms. The improvement was mainly in the allergic symptoms such as sneezing, itching, nasal discharge which can be referred to the action of omalizumab in reducing total IgE level with subsequent reduction of mast cells degradation and release of inflammatory and allergic mediators responsible for allergic nasal symptoms.

Post-operative total IgE level measured at 12 weeks interval showed also a significant difference $(\mathrm{p}=0.02)$ between study group A (Mean $=295.8 \pm 213.78)$ and study group B (Mean $=627.5 \pm 300.27)$. There was no statistically significant difference between the two study groups as regarding postoperative total IgE level measured at 4, 8, 24 weeks interval. This can be explained by understanding omalizumab pharmacokinetics and pharmacodynamics. Following subcutaneous adminis-tration, omalizumab is absorbed slowly, reaching peak serum concentrations after an average of 7-8 days, with a terminal half-life of 26 days $^{[28]}$. Despite that, within our study, we found that omalizumab action on total $\operatorname{IgE}$ level in AFRS patients remained up to 12 weeks post-injection. After that, Total $\operatorname{IgE}$ level began to rise again till it reached the same level of group B patients. Gan et al. in their proposal found that total IgE levels were not reduced in all patients post omalizumab therapy. They hypothesize that the reason for this was because omalizumab binds to $\operatorname{IgE}$ without changing its physiologic production. Hence, the absolute levels would therefore not be expected to change ${ }^{[8]}$. There was no significant difference between the two study groups as regarding changes in the post-operative endoscopic Phillpott-Javer staging scores $(p=0.144)$.

In our series, we did not face serious side effects in both groups. There were a few limitations in our study. The number of patients involved in this study was small. We used a single dose of $150 \mathrm{mg}$ omalizumab in our study irrespective to total IgE level. This allowed us to monitor the effect of a fixed dose of omalizumab on different total IgE levels. Finally, the optimal duration and dosage of omalizumab therapy for the treatment of AFRS have yet to be determined. Further studies are needed, however, this study is considered one of the very few randomized control trials testing the role of omalizumab in management of AFRS in comparison to a standard treatment modality (topical steroid).

\section{Conclusion:}

We suggest that omalizumab has more superior effect than local steroids in controlling nasal symptoms in AFRS patients despite the same endoscopic scores post-treatment. We also recommend further studies on omalizumab in AFRS, prolonged 
study periods for longer follow-up of patients in the future with determination of optimum dosage and duration of omalizumab therapy.

\section{Acknowledgements:}

This work was done in the Department of Otolaryngology in Ain Shams University, Egypt.

Financial support and sponsorship

Nil.

Conflicts of interest

There are no conflicts of interest.

\section{REFERENCES:}

1. Khattar VS, Hathiram BT. Allergic fungal rhinosinusitis. Otorhinolaryngology Clinics. 2009; (1): 37-44.

2. Ferguson BJ, Barnes L, Bernstein JM, et al. Geographic variation in allergic fungal rhinosinusitis. Otolaryngol Clin North Am. 2000; 33:441-449.

3. Laury AM, Wise SK. Allergic fungal rhinosinusitis. Am J Rhinol Allergy. 2013; 27: 26-27.

4. Halawi AM, Smith SS, Chandra RK. Chronic rhinosinusitis: Epidemiology and cost. Allergy Asthma Proceedings. 2013; 34: $328-334$.

5. Loftus PA, Wise SK. Allergic fungal rhinosinusitis: The latest in diagnosis and management. AdvOtorhinolaryngol. 2016; (79): 13-20.

6. Gan EC, Thamboo A, Rudmik L, et al. Medical management of allergic fungal rhinosinusitis following endoscopic sinus surgery: an evidence-based review and recommendations. International Forum of Allergy \& Rhinology (4). 2014; (9).

7. Bachert C, Pawankar R, Zhang L, et al. Chronic rhinosinusitis. World Allergy Organization Journal.2014; 7-25.

8. Gan EC, Habib AR, Rajwani A, et al. Omalizumab therapy for refractory allergic fungal rhinosinusitis patients with moderate or severe asthma. American journal of Otolaryngology-Head and neck medicine and surgery .2015; (36) 672-677.

9. Poetker DM, Jakubowski LA, Lal D, et al. Oral corticosteroids in the management of adult chronic rhinosinusitis with and without nasal polyps: an evidence-based review with recommendations. Int Forum Allergy Rhinol. 2013; 3: 104-20.

10. Poetker DM, Reh DD. A comprehensive review of the adverse effects of systemic corticosteroids. Otolaryngol Clin N Am. 2010; 43: 753-68.

11. Thamboo A, Manji J, Szeitz A, et al. The safety and efficacy of short-term budesonide delivered via mucosal atomization device for chronic rhinosinusitis without nasal polyposis. Int Forum Allergy Rhinol. 2014; 4: 397-402.

12. Rudmik L, Hoy M, Schlosser RJ, et al. Topical therapies in the management of chronic rhinosinusitis: an evidence-based review with recommendations. Int forum allergy rhinol. 2013; 3:281-98.

13. Mullings WP, Al-Salman R, Javer AR. Managing Allergic Fungal Rhinosinusitis .Current Otorhinolaryngology Reports. Springer Science + Business Media, 2018.

14. Gupta A, Shah N, Kamezwaran M, et al. Allergic fungal rhinosinusitis. Clin Rhinol An Int J .2012; 5:72-86.

15. Evans II MO and Coop CA. Novel treatment of allergic fungal sinusitis using omalizumab. Allergy Rhinol. 2014; 5:172174.

16. Tyler MA, Luong AU. Current understanding of allergic fungal rhinosinusitis. World Journal of OtorhinolaryngologyHead and Neck Surgery. 2018; 4: 179-185.

17. Mabry RL, Mabry CS. Allergic fungal sinusitis: the role of immunotherapy. Otolaryngol Clin North Am. 2000; 33 (2): 433-40.

18. Suri N, Bhavya BM. Allergic fungal rhinosinusitis: an overview on pathogenesis, early diagnosis and management. Int $\mathrm{J}$ Otorhinolaryngol Head Neck Surg. 2018; 4 (3): 694-700. 
19. Holgate S, Smith N, Massanari M, et al. Effects of omalizumab on markers of inflammation in patients with allergic asthma. Allergy. 2009; 64: 1728-1736.

20. Lin H, Boesel KM, Griffith DT, et al. Omalizumab rapidly decreases nasal allergic response and FceRI on basophils. J ALLERGY CLIN IMMUNOL.2004; 113 (2): 297-302.

21. Bent JP III, Kuhn FA. Diagnosis of Allergic Fungal Sinusitis. Otolaryngol Head Neck Surg. 1994; 111:580-88.

22. Chen JJ, Chen DL, Chen CJ. The LundMackay Score for Adult Head and Neck Computed Tomography. J Radiol Sci. 2011; 36: 203-208.

23. Philpott CM, Clark A, Javer AR. Allergic fungal rhinosinusitis, a new staging system. Rhinology.2011; 49: 318-323.

24. Galal N, Shawky A, El-Fouly M, et al. Level of total and specific fungus $\operatorname{IgE}$ in allergic fungal sinusitis: how it affects management and follow-up. Pan Arab Journal of Rhinology .2016; 06:45-50.

25. Kuhn FA, Javer AR. Allergic fungal sinusitis: a four-year followup. Am J Rhinol. 2000; 14: 149-56.

26. Luong A, Marple BF. Allergic fungal rhinosinusitis. Curr Allergy Asthma Rep. 2004; 4:465-470.

27. Tyler MA, Russell CB , Smith DE, et al. Large-scale gene expression profiling reveals distinct type 2 inflammatory patterns in chronic rhinosinusitis subtypes. $\mathrm{J}$ Allergy Clin Immunol. 2017; 139:10611064.

28. Lowe PJ, Tannenbaum S, Gautler A, et al. Relationship between omalizumab pharmacokinetics, IgE pharmacodynamics and symptoms in patients with severe persistent allergic (IgE-mediated) asthma.Br J Clin Pharmacol. 2009; 68(1): 61-76. 


\section{دوراوماليزوماب في علاج إلتهابات الجيوب الانفية الفطري التحسسي بار الدين مصطفي ومحمد أمير حسن وطارق حمدي و أنس عسكورة و مايكل منير}

قسم جر احة الانف و الأذن و الحنجرة, كلية الطب جامعة عين شمس , القاهرة , جمهورية مصر العربية

الخلفية: يرجع التهاب الجيوب الأنفية الفطري التحسي إلى التعرض المستمر للمستضدات الفطرية للفرد التأتبي.

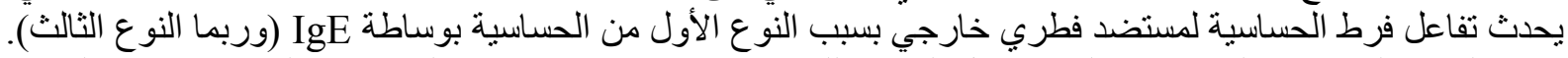

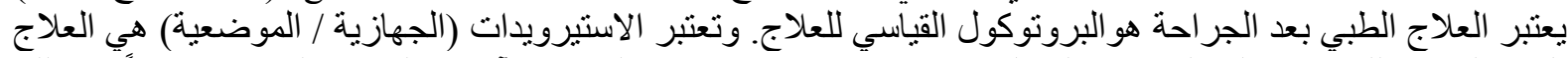

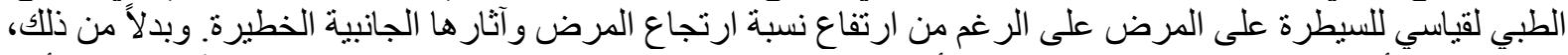

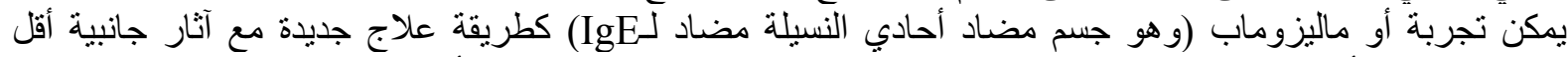

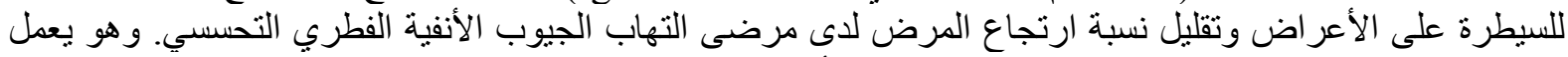
عن طريق إجهاض رد الفعل المناعي للفطريات الجيبية الأنفية من خلال منع إطلاق وسطاء الالتهابات التي تسبب التيب علامات وأعر اض الحساسية.

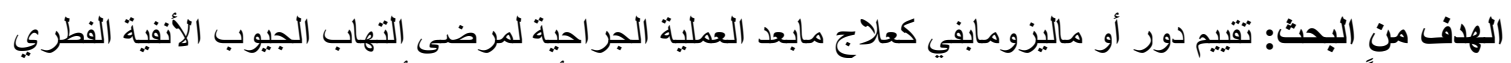

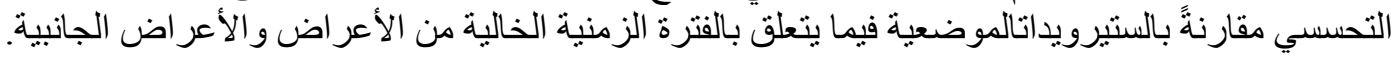

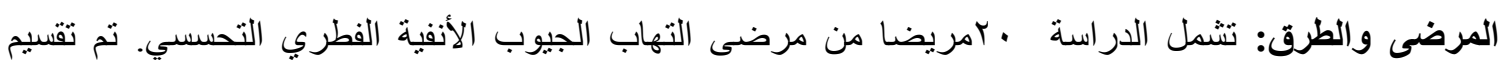

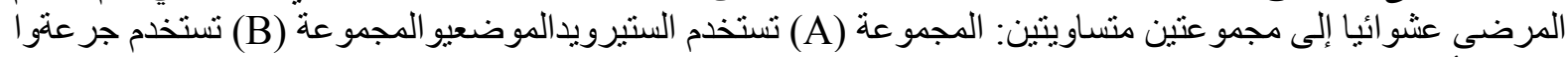

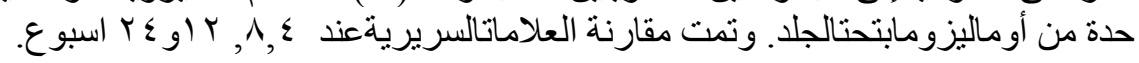

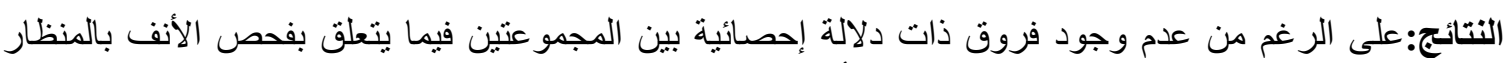

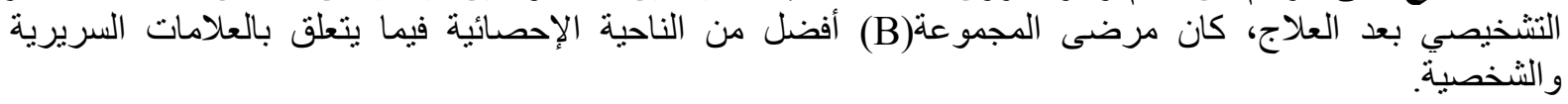

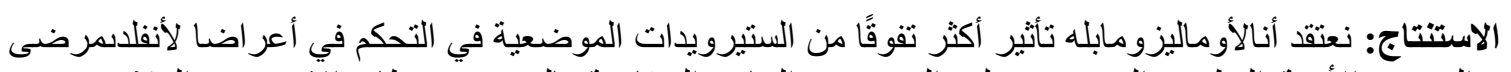

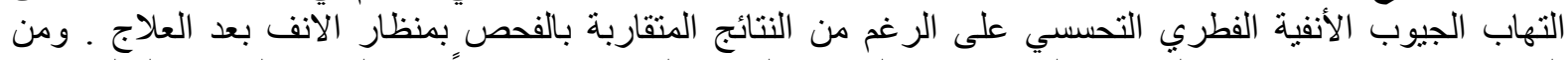

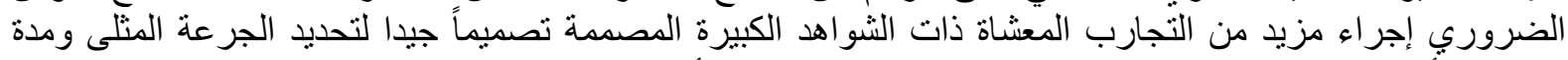
العلاج بالأوميزومابفي المرضى الذين يعانون من التهاب الجيوب الأنفية الفطري التحسسي. 